\title{
STUDIES ON GRAM-POSITIVE BACTERIA ISOLATED FROM LUNGS OF CAMEL
}

\author{
*Amgad A. Moawad; ${ }^{* *}$ Hala S. Ibrahim and Marwa M. Elsherbiny \\ * Dept. of Bacteriology, Mycology and Immunology, Fac. Vet. Med., \\ Kafrelsheikh Univ., Egypt
}

** Dept. of Microbiology, Animal Health Research institute, Dokki.,Giza, Egypt. E-mail: amgadprof 2003@ hotmail.com

\begin{abstract}
Out of 308 samples 205 from apparently healthy and 103 diseased lungs of slaughtered camels. The total number of positive samples was 203 (65.91\%) from which 124 (60.49\%) from apparently healthy and 79(76.70\%) from pneumonic lungs of camels.

The total number of isolates was 302 isolates from which 174 isolates from apparently healthy and 128 isolates from pneumonic lung of camels. The total number of Gram positive bacterial isolates was 132 (43.71\%) from which the incidence of Gram +ve isolates was 80 (45.98\%) and 52 (40.63\%) in apparently healthy and diseased lungs respectively as shown in table (3).

The most prevalent single Gram positive isolates from lungs of slaughtered camels were non haemolytic streptococci 17 samples (16.35\%) followed by Staphylococcus aureus 12 samples (11.54\%), Micococcus spp. 6 samples (5.77\%), Arcanobacterium pyogenes 3samples (2.89\%), Diplococccus pneumoniae 2 samples (1.92\%).
\end{abstract}


Regarding to the pathogenicity of some bacterial isolates in experimentally infected mice by $0.1 \mathrm{ml}\left(3 \times 10^{8} \mathrm{CFU} . \mathrm{ml}\right) \mathrm{I} / \mathrm{P}$. It was resulting in death to mice varying from $(40,60$, to 100\%) as pathogenicity of Staphylococcus aureus, Micrococcus spp and Arcanobacterium pyogenes respectively.

The most effective antimicrobial agents against some selected isolates obtained from lungs of camels were Cloxacillin, Gentamicin and Norfloxacin against Arcanobacterium pyogenes.

Ciprofloxacin, Gentamicin and Norfloxacin against, Micrococcus spp., non haemolytic streptococci and Staphycoccus aureus.

Key Words: Pathogenicity, pneumonic lung, antimicrobial agents.

\section{INTRODUCTION}

Camel plays vital socioeconomic roles and supports the survival of millions of people in Asia and Africa. It is being used as a source of protein, milk and hides as well as quiet and effective means of transport (Chowdhary, 1986).

Respiratory affections are the main causes of death among camel calves all over the world (Chowdhary, 1986 and Khanna et al., 1992).

Bacterial infection of lungs is one of the main causes of pneumonia (Thabet, 1994). Many bacteria were isolated from pneumonic lungs as Staphyloccus aureus, Streptococcus pneumoniae, Arcanobacterium spp and Micrococcus spp Thabet (1994), Amany (2000) and Azzam and Zaki (2006). 
The present work was aimed to study the Gram positive bacterial species infecting respiratory system of camels. For achieving the following points:

- Isolation and identification of Gram-positive bacteria recovered from apparently healthy and pneumonic lungs of camels.

- Determination of the pathogenicity of isolates to mice.

- Detecting the antibiogram against the isolated bacteria.

\section{MATERIALS AND METHODS}

\section{MATERIALS:}

\subsection{Samples for isolation:}

- 308 samples from imported slaughtered camels were collected from El-Basatein abattoir, Cairo-Egypt, The collected samples were 205 samples from apparently healthy and 103 samples had pathological lesions.

- All samples were kept in clean plastic ice bags in cooling container and transferred as soon as possible to the laboratory of Animal Health Research institute, Dokki, Egypt, for bacteriological examination.

- 1.2. Media used for isolation and cultivation of bacteria:

- 1.2.1. Fluid media:

- 1. 2.1.1. Nutrient broth: (Oxoid, Code CM1)

- 1.2.2. solid media:

- 1. 2.2.1. Nutrient agar medium: (Oxoid, Code, CM3)

- 1.2.2.2. Blood agar medium: (Oxoid, Code, CM55)

- 1.2.2.3. Mannitol salt agar: (Oxoid, Code CM85) 
- 1. 2.2.4. Edward's media: (Oxoid Code CM 27)

- 1.2.3. Semisolid media: (soft agar): (Cruickshank et al. 1975) This medium was used for the preservation of all isolates.

1.3. Media used for biochemical identification of the isolates:

All media used were prepared according to Cruickshank et al. (1975) and Koneman et al. (1988).

- 1.3.1. Peptone water 1\%: (Oxoid, Code L37)

- 1.3.2. Urea agar base: (Oxoid, CM53)

- 1.3.3. Nutrient gelatin: (Oxoid, CM35a)

- 1.3.4. Nitrate broth: (Difco, 268)

- 1.3.5. Sugar fermentation media: (Kreig and Holt, 1984)

- 1.3.6. Aesculin hydrolysis test medium: (modified from Erno and Stipkovits, 1973).

- 1.3.7. Arginine dehydrolase: (MacFaddin, 1976): used for Streptococcus identification.

\subsection{Stains used:}

- 1.4.1.Gram's stain: It was prepared according to Mackie and MacCarteny (1989).

- 1.4.2.Leishman stain: (Cruickshank et al.,1975)

1.5. Chemical and Reagents: It was prepared according to Koneman et al. (1988). 
- 1.5.1. $3 \%$ hydrogen peroxide for catalse test.

- 1.5.2. Tetra-methyl-p-phenylene diamine dihydrochloride $1 \%$ for oxidase test.

- 1.5.3. Solution I of $5 \% \alpha$-naphthol in absolute ethyl alcohol and solution II of $40 \%$ potassium hydroxide solution for Voges Proskauer test.

- 1.5.4. $40 \%$ urea medium (Oxoid SR 20): for urease test.

- 1.5.5. Reagent I of $0.8 \%$ sulfanilic acid in $10 \mathrm{~N}$ acetic acid and reagent II of $0.5 \% \alpha$-naphthylamine in $5 \mathrm{~N}$ acetic acid for nitrate reduction test.

- 1.5.6. $1 \%$ a queous solution of ferric ammonium citrate for aesculin hydrolysis test (Erno and Sitpkovits, 1973).

- 1.5.7. Diluted citrated plasma: for coagulase test.

- 1.5.8. Sodium hippurate for sodium hippurate hydrolysis test (Cruickshank et al., 1975).

- 1.5.9. $1 \%$ L. Arginine hydrochloride for arginine dehydrolase test..

- 1.5.10. Streile paraffin oil for Arginine dehydrolase test.

\subsection{Laboratory animals:}

\section{White mice:}

Swiss Webster white mice weighting 18 - 22 grams were used to measure the virulence of bacterial isolates. 


\subsection{Diagnostic chemotherapeutic agents: (Oxoid):}

Antimicrobial sensitivity discs were obtained from Oxoid. The sensitivity of bacterial isolates was tested against the following antimicrobial agent's disks: ciprofloxacin $(3 \mu \mathrm{g})$, cloxacillin $(5 \mu \mathrm{g})$, chloramphenicol $(30 \mu \mathrm{g})$, doxycyline $(30 \mu \mathrm{g})$, enrofloxacin $(5 \mu \mathrm{g})$, flumequine $(30 \mu \mathrm{g})$, gentamicin $(10 \mu \mathrm{g})$, norfloxacin $(10 \mu \mathrm{g})$, penicillin $(10 \mu \mathrm{g})$, streptomycin $(10 \mu \mathrm{g})$ and trimethoprim $(5 \mu \mathrm{g})$.

\section{METHODS:}

\subsection{Collection and preparation of samples:}

Samples were obtained from apparently healthy and diseased lungs which showing various macroscopic pathological changes of pneumonia. The samples were collected separately in sterile plastic ice bags and transported immediately to the lab for bacteriological examination.

\subsection{Bacteriological examination:}

\subsubsection{Cultivation:}

The surface was sterilized by hot spatula then opened by sterile scalpel. Sterile platinum loop was inserted inside the opening then inserted into nutrient broth also one gm from sample was put in $10 \mathrm{ml}$ of nutrient broth and incubated aerobically at $37^{\circ} \mathrm{C}$ for $24 \mathrm{hrs}$. The suspected colonies were picked up and subculture into nutrient agar and specific media plates for each bacteria to confirm their purity then into nutrient agar slopes for identification. 


\subsubsection{Identification of bacterial isolates (Fineglod and Martin, 1982 and Quinn et al., 1994):}

Cultivated plates were examined after $24-48 \mathrm{hrs}$ incubation at $37^{\circ} \mathrm{C}$ for any bacterial growth. Colonies were identified according to:

\subsubsection{Culture characters:}

The cultural characteristic of each purified isolate were studied on solid madia according to their shape, size ,elevation ,structure of surface, colour, pigment and type of hemolysis .

\subsubsection{Microscopical examination:}

The isolated organisms were classified according to shape, size, arrangement and gram staining reaction .

\subsubsection{Biochemical identification:}

\subsection{Gram positive cocci:}

By using the coagulase, oxidase and catalase production tests as shown in the Table (1).

Table (1): Illustrates the characteristic biochemical tests for Gram positive cocci (Quinn et al., 1994).

\begin{tabular}{|c|c|c|c|}
\hline Gram positive cocci & Catalase & Coagulase & Oxidase \\
\hline Streptococci spp & - & - & - \\
\hline Staphylococcus aureus & + & + & + \\
\hline Others Staphylococci spp (non pathogenic) & + & - & - \\
\hline Micrococci spp & + & - & + \\
\hline Enterococci spp & - & - & - \\
\hline
\end{tabular}


* Classification of Genus Staphylococcus into species:

Using the following characteristics:

Growth anaerobically using oxidase test, Vogas-proskauer test, Coagulase test, Sugar fermentation test, Nitrate reduction test, Arginine hydrolysis and Urease test.

\section{* Classification of Genus Streptococcus:}

\section{Using the following characteristics:}

Growth at $10^{\circ} \mathrm{C}$, growth at $45^{\circ} \mathrm{C}$, growth at $6.5 \% \mathrm{NaCl}$, growth at pH 9.6, hemolysis on sheep blood agar, Arginine hydrolysis test, Hippurate hydrolysis test and growth under anaerobic condition.

\subsubsection{Gram positive non-spore forming rods (Corynebacterium): Using the following characteristics:}

Catalase production, Nitrate reduction, Urease activity, Gelatinase and Sugar fermentation test

\subsection{Pathogenicity test of bacterial isolates in mice:}

a) Preparation of bacterial suspension: (Stamp et al. 1959).

The bacterial suspension was made by plate washing technique. From the original culture, this was plated onto $10 \%$ sheep blood agar plate and then incubated for $24 \mathrm{hrs}$ at $37^{\circ} \mathrm{C}$. The inoculated plate was flooded with $5 \mathrm{ml}$ saline and the colonies were removed from the solid medium by gentle rubbing with a glass rod, the resultant suspension were adjusted to be contained on average of $3 \times 10^{8}$ colony forming unite (flu) per $\mathrm{ml}$ (adjusted to a $0.5 \mathrm{McFarland}$ standard). 
b) Route of injection (Wessman, 1964):

Five mice were used for each isolate; they were injected from the prepared solution using sterile disposable plastic syringes. Each mouse from each group was injected by $0.1 \mathrm{ml}$ of bacterial suspension I/P for the detection of pathogencity, mortalities rates and the pathogencity rate were calculated

2.5. Susceptibility of the isolated strains to various antimicrobial agents:

The disk diffusion technique was adapted according to Fineglod and Martin (1982).

\subsubsection{Preparation of the standardized inoculums:}

- Four or five typical colonies of similar morphology were transferred using a sterile loop to a tube containing $5 \mathrm{ml}$ of sterile Mueller Hinton broth.

- The broth was incubated at $37^{\circ} \mathrm{C}$ for $2-8 \mathrm{hrs}$ for its turbidity exceeds that of the standard McFerland tube 0.5 barium sulphate tube $(0.5 \mathrm{ml}$ of $1.175 \%$ barium chloride hydrate to $99.5 \mathrm{ml}$ of $1 \%$ sulphuric acid). The turbidity was adjusted to match a McFerland 0.5 barium sulphate standard tube by adding sterile saline using adequate light

\subsubsection{Inoculation of the tested plates:}

- A sterile cotton swab was dipped into the standardized bacterial suspension. 
- Excess fluid was removed by rotating the swab with firm pressure against the inside wall of the tube above the fluid level.

- The swab was then used to streak the dried surface of MullerHinton agar plate in three different planes by rotating the plate approximately (60) degree each time to ensure an even distribution of the inoculation.

- The plate lids were placed and the inoculated plates were allowed to remain on a flat level surface undistributed for 3 to 5 minutes to allow the adsorption of excess moisture then the disks were applied.

\subsubsection{Application of antibiotics and chemotherapeutic discs:}

- With fine-pointed forceps, the selected antimicrobial discs were placed onto the inoculated plates.

- The discs were distributed evenly in a manner such as to be no closer than $15 \mathrm{~mm}$ from the edge of Petri dish and so that no two discs were closer than $24 \mathrm{~mm}$ from center to center.The plates were then incubated at $37^{\circ} \mathrm{C}$ for $24 \mathrm{hrs}$.

\subsubsection{Interpretation of the zone of inhibition:}

By measuring clear zone of inhibition of growth produced by diffusion from the discs into the surrounding medium.according to the Koneman et al. (1983) and Oxoid Manual (1982) Table (2). 
Studies On Gram-Positive Bacteria Isolated From Lungs ...

Table (2): Interpretation of zones of inhibition for antibacterial susceptibility.

\begin{tabular}{|c|c|c|c|c|}
\hline \multirow{2}{*}{ Antibiotics and chemo therapeutic agents } & \multirow{2}{*}{ Symbol } & \multirow{2}{*}{ Conc. in $\mu \mathrm{g}$} & \multicolumn{2}{|c|}{ Diameter of inhibition zone } \\
\hline & & & Sensitive & Resistance \\
\hline Chloramphenicol & $\overline{\mathrm{C}}$ & 30 & $\geq 18$ & 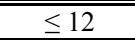 \\
\hline Ciprofloxacin & Cip & 5 & $\geq 21$ & $\leq 15$ \\
\hline Cloxacillin & OB & 5 & $\geq 18$ & $\leq 14$ \\
\hline Doxycycline & Do & 30 & $19-23$ & $15-18$ \\
\hline Enrofloxacin & Enr & 5 & $\geq 18$ & $\leq 14$ \\
\hline Flumequine & UB & 30 & $\geq 16$ & $\leq 13$ \\
\hline Gentamicin & $\mathrm{CN}$ & 10 & $\geq 15$ & $\leq 12$ \\
\hline Norfloxacin & Nor & 10 & $\geq 17$ & $\leq 12$ \\
\hline Pencillin G & $\mathrm{P}$ & 10 & $\geq 19$ & $\leq 14$ \\
\hline Streptomycin & $\mathrm{S}$ & 10 & $\geq 15$ & $\leq 11$ \\
\hline Trimethoprim & $\mathrm{Tr}$ & 5 & $\geq 16$ & $\leq 10$ \\
\hline
\end{tabular}

All discs obtained from Oxoid Company.

\section{RESULTS}

\subsection{Incidences and types of positive cases yielded single or mixed bacterial isolates from lungs of slaughtered camels:}

Table (3): The incidences and types of positive cases yielded single or mixed bacterial isolates from lungs of slaughtered camels.

\begin{tabular}{|c|c|c|c|c|c|c|c|c|c|c|c|c|}
\hline 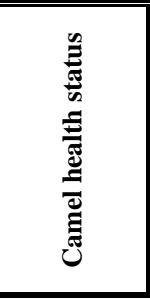 & 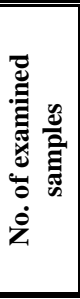 & 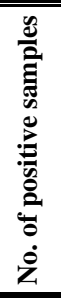 & $\%^{*}$ & 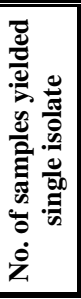 & $\%^{* *}$ & 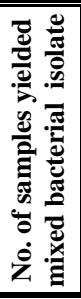 & $\%^{* * *}$ & 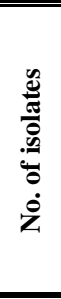 & 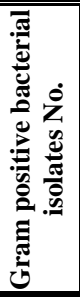 & $\%^{* * * *}$ & 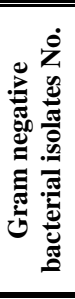 & $\%^{* * * *}$ \\
\hline $\begin{array}{c}\text { Apparently } \\
\text { healthy }\end{array}$ & 205 & 124 & 60.49 & 74 & 59.68 & 50 & 40.32 & 174 & 80 & 45.98 & 94 & 54.02 \\
\hline $\begin{array}{c}\text { Diseased } \\
\text { (pneumonic) }\end{array}$ & 103 & 79 & 76.70 & 30 & 37.97 & 49 & 62.03 & 128 & 52 & 40.63 & 76 & 59.38 \\
\hline Total & 308 & 203 & $\begin{array}{l}65.91 \\
\end{array}$ & 104 & 51.23 & 99 & 48.77 & 302 & 132 & 43.71 & 170 & 56.29 \\
\hline
\end{tabular}

* The percentage was calculated according to number of examined samples of each camel health status.

** Percentage was calculated according to total No. of positive samples of each camel health status.

*** Percentage was calculated according total number of isolates (174) from apparently healthy and (128) from pneumonic camel lungs.

$\overline{\text { Kafrelsheikh Vet. Med. J. Vol. } 9 \text { No. } 1 \text { (2011) }}$ 
Amgad A. Moawad et., al.

Table (4): The incidences and types of bacterial isolates recovered from apparently healthy and pneumonic lungs of slaughtered camels.

\begin{tabular}{|c|c|c|c|c|}
\hline \multirow{2}{*}{ Types of bacteria } & \multicolumn{2}{|c|}{ Apparently healthy lungs (124 samples) } & \multicolumn{2}{|c|}{ Pneumonic lungs (79 samples) } \\
\hline & No. of isolates & $\%^{*}$ & No. of isolates & $\%^{*}$ \\
\hline \multicolumn{5}{|l|}{ a) Gram positive isolates } \\
\hline Arcanobacterium pyogenes & 0 & 0 & 6 & 4.69 \\
\hline Diplococcus pneumoniae & 0 & 0 & 10 & 7.81 \\
\hline Micrococcus spp. & 18 & 10.34 & 9 & 7.03 \\
\hline Non hemolytic Streptococci & 26 & 14.94 & 6 & 4.69 \\
\hline Staphylococcus aureus & 36 & 20.7 & 21 & 16.40 \\
\hline Total & 80 & 45.98 & 52 & 40.62 \\
\hline
\end{tabular}

N.B: Total number of bacterial isolates from apparently healthy lung were 171 including gram positive \&gram negative ones while total number of bacterial isolates from pneumonic lungs were 128 including also gram positive \& and gram negative bacteria.

*The percentage was calculated according to the total number of bacterial isolates from each camel health status.

Table (5): The incidences and types of single isolated bacterial isolates recovered from both apparently healthy and pneumonic lungs of slaughtered camels.

\begin{tabular}{|c|c|c|c|c|c|c|}
\hline \multirow{2}{*}{ Isolated microorganisms } & \multicolumn{2}{|c|}{$\begin{array}{c}\text { Total positive } \\
\text { samples from lungs }\end{array}$} & \multicolumn{2}{|c|}{$\begin{array}{l}\text { Positive samples from } \\
\text { apparently healthy lungs }\end{array}$} & \multicolumn{2}{|c|}{$\begin{array}{c}\text { Positive samples from } \\
\text { pneumonic lungs }\end{array}$} \\
\hline & No. & $\% *$ & No. & $\%$ & No. & $\%$ \\
\hline \multicolumn{7}{|l|}{ a) Gram positive isolates } \\
\hline Arcanobacterium pyogenes & 3 & 2.89 & 0 & 0 & 3 & 10 \\
\hline Diplococcus pneumonia & 2 & 1.92 & 0 & 0 & 2 & 6.67 \\
\hline Micrococcus spp. & 6 & 5.77 & 4 & 5.41 & 2 & 6.67 \\
\hline Non hemolytic Streptococci & 17 & 16.35 & 16 & 21.62 & 1 & 3.33 \\
\hline Staphylococcus aureus & 12 & 11.54 & 11 & 14.86 & 1 & 3.33 \\
\hline Total & 40 & 38.4 & 31 & 41.8 & 9 & 30 \\
\hline
\end{tabular}

* The percentage was calculated according to the total number of positive samples(104) in all lung samples, (74) in apparently healthy lungs and (30) in pueumonic lungs.

$\overline{\text { Kafrelsheikh Vet. Med. J. Vol. } 9 \text { No. } 1 \text { (2011) }}$ 
Studies On Gram-Positive Bacteria Isolated From Lungs ...

Table (6): Pathogenicity test of Gram positive bacterial isolates recovered from lungs of slaughtered camels.

\begin{tabular}{|c|c|c|c|c|c|c|c|c|c|}
\hline \multirow{2}{*}{ Examined bacteria } & \multicolumn{7}{|c|}{ No. of died mice/ day } & \multirow{2}{*}{ Total } & \multirow{2}{*}{$\% *$} \\
\hline & 1 & 2 & 3 & 4 & 5 & 6 & 7 & & \\
\hline Arcanobacterium pyogenes & 1 & 1 & 2 & 1 & 0 & 0 & 0 & $5 / 5$ & $100 \%$ \\
\hline Diplococcus pneumoniae & 3 & 2 & 0 & 0 & 0 & 0 & 0 & $5 / 5$ & $100 \%$ \\
\hline Micrococcus spp. & 1 & 2 & 0 & 0 & 0 & 0 & 0 & $3 / 5$ & $60 \%$ \\
\hline Non hemolytic Streptococci & 0 & 0 & 1 & 1 & 0 & 0 & 0 & $2 / 5$ & $40 \%$ \\
\hline Staphylococcus aureus & 0 & 0 & 0 & 1 & 1 & 0 & 0 & $2 / 5$ & $40 \%$ \\
\hline
\end{tabular}

*The percentage was calculated according to the number of examined mice of each strain.

Table (7): The antibiotic and chemotherapeutic agents of Gram positive bacterial isolates recovered from apparently healthy and pneumonic lungs of slaughtered camels.

\begin{tabular}{|c|c|c|c|c|c|c|}
\hline Tested pathogen & 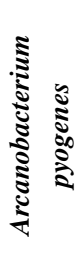 & 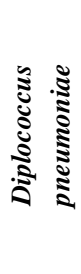 & 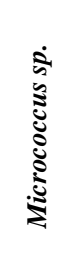 & 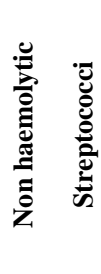 & 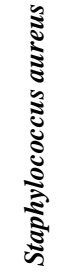 & Total \\
\hline Chloramphenicol & $\mathrm{R}$ & + & ++ & $\mathrm{R}$ & + & 3 \\
\hline Ciprofloxacin & $\mathrm{R}$ & + & ++ & +++ & ++ & 4 \\
\hline Cloxacillin & ++ & ++ & ++ & + & +++ & 5 \\
\hline Doxycycline & + & $\mathrm{R}$ & $\mathrm{R}$ & $\mathrm{R}$ & + & 2 \\
\hline Enrofloxacin & ++ & ++ & +++ & +++ & +++ & 5 \\
\hline Flumequine & $\mathrm{R}$ & + & $\mathrm{R}$ & + & $\mathrm{R}$ & 2 \\
\hline Gentamicin & + & ++ & ++ & + & ++ & 5 \\
\hline Norfloxacin & ++ & +++ & +++ & ++ & +++ & 5 \\
\hline Pencillin & $\mathrm{R}$ & $\mathrm{R}$ & + & + & $\mathrm{R}$ & 2 \\
\hline Streptomycin & $\mathrm{R}$ & $\mathrm{R}$ & $\mathrm{R}$ & $\mathrm{R}$ & $\mathrm{R}$ & 0 \\
\hline Trimethoprim & $\mathrm{R}$ & $\mathrm{R}$ & $\mathrm{R}$ & $\mathrm{R}$ & $\mathrm{R}$ & 0 \\
\hline
\end{tabular}

$-\mathrm{R}=$ Resistant

$-+=$ Sensitive

$-++=$ Wide Sensitive zone

$-+++=$ Very wide Sensitive zone

$\overline{\text { Kafrelsheikh Vet. Med. J. Vol. } 9 \text { No. } 1 \text { (2011) }}$ 


\section{DISCUSSION}

Bacterial infection of the lung was one the main cause of pneumonia in camels (Rana et al., 1993; Thabet, 1994; Alhendi, 2000 and Seddek, 2002).

The present study is a trial to find the pathogenic gram positive bacteria that were associated with lung of camel, also to study its pathogenicity and their antibacterial sensitivity to control bacterial pneumonia in camels.

Several hygienic factors may be predisposing causes of respiratory disease. These including long period without food, keeping in dirty stalls Baba et al., 1994) and transportation as camels come yearly from North of Sudan to south of Egypt and collected then remained for several weeks in daraw quarantine, Aswan, Egypt. Cold, raining and dust during winter are predisposing factors for respiratory infection (Ning et al. 1998).

As clear from Table (3) that bacteriological examination of 308 camel lung samples (205 apparently healthy and 103 pneumonic) revealed that 203 samples were bacteriologically positive with an incidence of $65.91 \%$. These result was similar to that reported by Mahmoud et al. (1988) who found that $67.3 \%$ of lung samples were bacteriologically positive but Lower incidences were recorded by Ebtesam et al. (2009) and Moustafa (2004) who obtained $47.06 \%$ positive samples, while higher prevalence was recognized by Amany (2000) who had $86.24 \%$ positive samples. 
Among 203 bacteriological positive lung samples, 124 (60.49\%) of apparently healthy lungs were bacteriological positive which partially confined with Thabet (1994) who his incidence was (71.8\%) and disagreed with Azzam and Zaki (2006) who recorded lower prevelance $(26.66 \%)$.

Meanwhile ,79 (76.7\%) of pneumonic lungs were culturally positive for bacteria which partially agreed with Azzam and Zaki (2006) who found that $(79 \%)$ of pneumonic samples were bacteriological positive . Higher incidences were estimated by Moustafa (2004) who recorded (96\%) of pneumonic samples were bacteriological positive. Lower percentages were recorded by Fatma et al. (2001) who found $(56 \%)$ of pneumonic samples were bacteriological positive.

The isolated bacteria may be present singly or mixed with others. It was noticed that out of 203 bacterial positive lungs, 104 (51.23\%) samples had single infection that partially agreed with Amany (2000) who recovered single isolates from $(65 \%)$ of lung samples. On the other hand, $99(48.77 \%)$ samples yielded mixed infection who found that was nearly similar to Nagi et al. (1997) who found that (43.85\%) yielded mixed infected samples.

In the present study, the incidences of samples yielded single and mixed infection from apparently healthy lungs of camels were 74 $(59.68 \%)$ and $50(40.32 \%)$, respectively, this result disagreed with Azzam and Zaki (2006) who recorded that the incidence were (85.71\%) and (14.29\%) for single and mixed samples of apparently healthy lung of camels, respectively. 
On the other hand, prevalence of pneumonic lung samples yielded single isolates was $30(37.97 \%)$ which was approximately similar to Moustafa (2004) who recorded the incidence of samples yielded single isolates from pneumonic lungs was (41.7\%).

The incidence of samples yielded mixed isolates from pneumonic lungs was 49 (62.03\%) which confined to some extent Moustafa (2004) who found that $(58.3 \%)$ of samples yielded mixed isolates from pneumonic lungs.

These findings declared that the highest samples yielded single bacterial isolates than mixed ones were found in apparently healthy lungs, which agreed with Thabet (1994). Meanwhile, the contrast occurs as the highest samples yielded mixed isolates were more than that yielded single

The current investigations revealed that 302 bacterial isolates recovered from lungs of slaughtered camels classified as 132 (43.71\%) Gram positive and 170 (56.29\%) Gram negative isolates out of which, 174 were recovered from apparently healthy lungs that classified as 80 (45.98\%) of Gram positive and 94 (54.02\%) of Gram negative isolates. These results were partially confined with Moustafa (2004) and disagreed with Amany (2000) who isolated (78.13\%) of Gram positive and $(21.88 \%)$ of Gram negative bacteria.

However, the number of isolates were 128 from pneumonic lungs, distributed as $52(40.63 \%)$ of Gram positive and 76 (59.38\%) of Gram negative isolates which were nearly in accordance with Amer et al. (2002) who found that the incidence of Gram positive were (54.7\%) and 
(45.33\%) of Gram-negative isolates respectively, and disagreed with AlDoughaym et al. (1999) who had (82.4\%) of Gram positive and (15\%) of Gram negative isolates from pneumonic lungs.

These variations in our data compared with others may be due to location, country, husbandary, feeding and immunity.

It was noticed from Table (4) that among 174 bacterial isolates recovered from 124 apparently healthy lungs, Staphylococcus aureus was the most common Gram positive bacteria with a prevalence of 36 (20.7\%) followed by non haemolytic streptococci and Micrococcus spp. with incidence of $26(14.94 \%)$ and 18 (10.34\%), respectively. These results were supported by with Aly et al. (2004) who found that Staph. aureus was the main Gram positive isolate from apparently healthy lungs with an incidence of (22.2\%). Lower percentages were detected by $\mathbf{N a g i}$ et al (1997) and Moustafa (2004) who isolated S. aureus from apparently healthy lungs with a prevalence of $6.25 \%$.

These results indicated that apparently healthy lungs act as a reservoir for many species of pathogenic and potential pathogenic microorganisms that under stress factors such as changes in the hygiene, environmental and climatic conditions may play a role in the onset of pneumonia Zubair et al. 2004). This concept was supported in the present study by the fact that a number of bacteria were isolated from 124 samples which showed no pathological lesions.

It was clear from Table (4) that out of 128 bacterial isolates from 79 pneumonic lungs. the most predominant isolate of Gram-positive bacteria was Staphylococcus aureus with a prevalence of 21 (16.40\%) 
followed by Diplococcus pneumoniae with incidence of 10 (7.81\%), Micrococcus spp. 9 (7.03\%) and lastly, Arcanobacterium pyogenes and non haemolytic Streptococci with an incidence of 6 (4.69\%) in each. This result was in accordance with Fuerst (1978) who reported that the main isolated bacteria from pneumonia were Staph. aureus and haemolytic streptococci.

The incidence of Staphylococcus aureus was similar to Seddek (2002) who isolate it with a percentage of $16.92 \%$ from pneumonic lungs.

Higher incidences were detected by Asil et al. (2004) who isolated Staph. aureus in incidence of (34.6\%). While lower percentage was showed by Amer et al. (2002) who isolated Staphylococcus aureus from $9.4 \%$ of pneumonic lungs.

Incidence of Diplococcus pneumoniae was partially agreed with Amer et al. (2002) who isolated Diplococcus pneumoniae from (6.7\%) of pneumonic lungs. Higher incidences were recognized by Seddek (2002)) who isolated Diplococcus pneumoniae from (11.77\%) of pneumonic lungs.

Incidence of Micrococcus spp. was agreed with Seddek (2002) who showed a percentage of $7 \%$ from pneumonic lungs.

Incidence of Arcanobacterium pyogenes and non haemolytic Streptococci is are partially agreed with Fatma et al. (2001).

Concerning Gram positive isolates, it was found that the one of highest incidence was non haemolytic Streptococci in 16 samples with an incidence of (21.62\%) then Staphylococcus aureus 11 (14.86\%) and Micrococcus spp. 4 (5.41\%). 
Also Table (5) explains that 30 samples yielded single bacterial isolates from pneumonic lungs of slaughtered camels and the most prevalent member of Gram positive bacteria belonged to Arcanobacterium pyogenes 3 (10\%) followed by Diplococcus pneumoniae and Micrococcus spp. with an incidence of $2(6.67 \%)$ in each and lastly, non haemolytic Streptococci and Staphylococcus aureus with an incidence of $1(3.33 \%)$ in each.

These findings were partially agreed with Amany (2000) who isolated Staphylococcus aureus, Streptococcus pneumoniae, Arcanobacterium pyogenes and Micrococcus spp. which isolated from pneumonic lungs with prevalence of $(5.77 \%),(7.69 \%),(10.58 \%)$ and $(4.8 \%)$, respectively.

The incidence of Staphylococcus aureus was similar to Azzam and Zaki (2006) who recorded its incidence of (4\%) from pneumonic samples while this finding was lower than Moustafa (2004) and Selim (2003) who obtained $18.18 \%$ of Staphylococcus aureus from pneumonic lungs.

The incidence of Diplococcus pneumoniae is in contrast with Moustafa (2004) and Azzam and Zaki (2006) who isolated it in incidence of (14\%) from pneumonic lungs.

However, Table (5) noticed that out of 104 samples revealed single isolates of bacteria, 74 samples from apparently healthy lungs with an incidence of $(71.15 \%)$ and 30 samples from pneumonic lungs with an incidence of $(28.85 \%)$ yielded single isolates. The higher number of samples yielded single isolates was recovered from apparently healthy lungs. The recovered organisms were classified into two categories, Gram positive and Gram negative bacterial isolates. The most predominant Kafrelsheikh Vet. Med. J. Vol. 9 No. 1 (2011) 
Gram positive single bacterial isolates recovered from both apparently healthy and pneumonic lungs were non haemolytic Streptococci with an incidence of $17(16.35 \%)$ followed by Staphylococcus aureus 12 (11.54\%), Micrococcus spp. 6 (5.77\%), as well as Arcanobacterium pyogenes and Diplococcus pneumoniae with an incidence of $(2.89 \%)$ in each.

Concerning in-vitro antibacterial sensitivity, it was clear from Table (10) and (11), that there is a marked difference between the sensitivity to antibiotics between different bacterial isolated from apparently healthy and pneumonic lungs of slaughtered camels.

As shown from Table (12) that the most effective antibiotics against Gram positive isolates from apparently healthy and pneumonic lungs of camels were Cloxacillin, Enrofloxalin, Gentamicin and Norfloxacin followed by Ciprofloxacin, Chloramphenicol, then Doxycycline, Flumequine and Pencillin.

These findings were concided with Amany (2000), Al-Tarazi and El-Sheikh (2006) who found that most of isolates from pneumonic lungs of camels were sensitive to Ciprofloxacin, Enrofoxacin and Gentamicin and partially agreed with Hanea and Omnia (2002).

Diplococcus pneumoniae was sensitive to Norfloxacin followed by Cloxacillin, Enrofloxacin, Gentamicin then Chloramphenical, Ciprofloxacin and Flumequuine, Meanwhile, most of the tested isolated were resistant to Doxycycline, Pencillin, Streptomycin and Trimethoprim. Similar results were obtained also by Aly et al. (2004) and Amer et al. (2002). 
Most of Micrococcus spp. proved to be highly sensitive to Enrofloxacin and Norfloxacin then Chloramphenicol, Ciprofloxacin, Cloxacillin and Gentamicin followed by Penicillin but it was resistant to Doxycycline, Flumequine, Streptomycin and Trimethoprim that was confirmed by Fatma et al. (2001) and Seddek (2002).

Staphylococcus aureus was highly sensitive to Cloxacillin, Enrofloxacin and Norfloxacin followed by Ciprofloxacin and Gentamicin then Chlorampenicol and Doxycycline but it was resistant to Flumequine, Penicillin, Streptomycin and Trimethoprim which were in accordance with Azzam and Zaki (2006) and Ebtesam et al. (2009).

It was clear that most of bacterial isolates were resistant to most antibiotics and this may be attributed to wrong dosage, duration of treatment and route of administration (Amstutz et al., 1982).

These variations in sensitivity may be due to bacterial nature, distribution of bacteria or regional difference and plasmid helping in the formation of resistant strains. In consideration of the most effective in vitro antibacterial agents against all tested isolates, Enrofloxacin should be the drug of choice in controlling pneumonia in camel.

\section{REFERENCES}

- Alhendi, A. A. B. (2000): Common diseases of camels (Camelus dromedaries) in Eastern province of Saudi Arabia. Pakistan. Vet. J., 20 (2): 97-99.

- Amany, N. D. A. (2000): A contribution towards the bacteria harboring and affecting the respiratory tract of camel. M.V.Sc. Thesis. Fac. Vet. Med. Cairo Univ. 
- Amer, H. A.; Omnia, F. H. B. and Salem, S. A. H. (2002): "Diagnosis of some respiratory diseases in camel calves". Minufyia Vet. J., 2(1): 113-135.

- Amstutz, H.; Morte, R. and Armostrong, C. (1982): Antimicrobial resistance of strains of Pasteurella spp. isolated from feedlot cattle. Bovine Practice, 16: 52-55.

- Al-Doughaym, A. M.; Mustafa K. M. and Mohamed, G. E. (1999): Aetiological study on pneumonia in camel (Camelus Dromedarius) and in vitro antibacterial sensitivity pattern of the isolates. Pakistan J. Biol. Sci, 2(4): 1102-1105.

- Al-Tarazi, Y. H. and El-Sheikh, H. (2006): In vitro sensitivity against bacterial pathogens isolated from pneumonic lungs of camels in Jordan. J. of Camel Practice and Research, 13 (2): 157-163.

- Aly, A. A.; Soliman, A. S. and Gobran, R. A. (2004): Bacteriological and pathological studies on some lung affections of camels at Kalubia governate. Mansoura Vet. Med. J. Vol., VI (1): 75-86

- Asil E.; Abdul Khalig, B. and Adam, A. (2004): Studies on pathological changes of condemned lungs of one humped camels (camelus dromedarius). Deutscher Tropentag octobar 5-7 Brelin Rural poverty Reduction through research for development.

- Azzam, I. M. and Zaki, H. M. (2006): Laboratory investigation on bacterial pneumonia in camels. Egypt. J. Comp. Path. and Clinic Path. 19(1): 319-344.

- Baba, S. S.; Amball, A. G.; Zaria, L. T. and Kalra, S. (1994): Abattoir records of slaughtered camels. Bull. Anim. Hlth. Prod. Afr., 42(3):253-257. 
- Chowdhary B. (1986): Some important biological and production characters of the Bikaner camels. Ind. J. Anim. Prod. Manag., 2(3): 145-151.

- Cruickshank, R.; Dugid, J. P.; Marmion, B. P. and Swain, R. H. (1975): The Practice Medical Microbiology, 12th Ed. Vol. II Churchill Living Stone, Edinburgh, London and New York.

- Ebtesam, M. M.; Ibrahim, H. M. and Sharaf, E. M. (2009): Some studies on bacteria isolated from respiratory system of apparently healthy camels in Qulybia governorate.Zag., Vet.J., Vol. 37(1): 62-66.

- Erno, H. and Stipkovits, L. (1973): Bovine Mycoplasma :cultural and biochemical studies. Acta Vet. Scand. 14: 450-463.

- Fatma, M. Darwish; Hammad, A. M. and Hala, S. Ibrahim (2001): Pathological studies on pneumonia in camels with special reference to mycotic and bacterial infection. J. Egypt. Vet. Med. Ass., 61 (2): 143-172.

- Finegold, S. M. and Martin, W. T. (1982): Diagnostic Microbiology. $6^{\text {th }}$ Ed., The C.V. Mosby Company U.S.A.

- Fuerst, $\boldsymbol{R}$. (1978): Microbiology in health and disease. $14^{\text {th }}$ Ed., W.B. Saunders Co., Philadelphia, USA.

- Hanea, A. A.A. and Omnia, F. H. B. (2002): Diagnosis of some respiratory diseases in camel calves. Minufyia.Vet. Med. J., 2 (1).

- Khanna, N. D.; Tandon, S. N.; Sahani ,M. S.; Allen ,W. R.; Higgins, A. J.; Mayhew, I. G.; Snow ,D. H. and Wade, J. F. (1992): Calf mortality in Indian camels. Proceedings of the first international camel conference, Dubai, $2^{\text {nd }}-6^{\text {th }}$ February 1992: 89-92. 
- Koneman, E. W.; Allen, S. D.; Dowel, V. R. and Sommers, H. M. (1983): Colour Atlas and Text Book of Diagnostic Microbiology. $2^{\text {nd }}$ Ed. J.B. Lippincott Co., New York, London.

- Koneman, E. W.; Allen, S. D.; Dowel, V. R.; Sommers ,H. M.; Janda, W. M. and Winn, W. C. (1988): Colour Atlas and Text Book of Diagnostic Microbiology. $3^{\text {rd }}$ Ed. J. B. Lippincott, Co, Philadelphia, U.S.A.

- Kreig, N. R. and Holt, J. G. (1984): Bergey's Manual of Systemic Bacteriology. $8^{\text {th }} \mathrm{Ed}$. Williams and Wilkins, Baltimore, London: 11117.

- MacFaddin, J. E. (1976): Biochemical tests for identification of medical bacteria. ${ }^{\text {st }} \mathrm{Ed}$.

- Mackie, T. J. and MacCarteny, J. E. (1989): Practical Medical Microbiology. $13^{\text {th }}$ Ed. Churchill Livingstone, London.

- Mahmoud, A. Z.; Sabah, I. M. and El-yas, A. H. (1988): "A study on lung affections of camels (camelus dromedarius) in Assuit governorate". Assuit Vet. Med. J., 20: 93-99.

- Moustafa, A. H. (2004): "A study on some aerobic bacterial causes of respiratory affection in slaughtered camels in Dakahlia governate". Assiut Vet. Med. J., Vol 5o (102): 95-105.

- Nagi, A.; Gaballh, M. S.; El-Mashad, A. L. and Abd El-Aziz, A. M. (1997): Pathological studies on some lung affections in camel (Camelus Dromedarius), at Kalubia province. Benha Vet. Med. J., 8 (2): 209-223. 
- Ning,J.;Nuaitae,C.and Xuanren,Z.(1998): Study on pneumoconiosis in Bactrian camels. Chin. J. Vet. Sci., 18(2):186-190.

- Oxoid Manual (1982): The Oxoid culture media, ingradient and other laboratory service. $5^{\text {th }}$ Ed., Oxoid Limited, Hampshire, R.G.240 PW, England.

- Quinn, P. J.; Carter, M. E.; Markey, B. K. and Carter, G. R. (1994): Clinical Veterinary Microbiology.Wolfe Publishing Livestock,London.

- Rana, M. Z.; Ahmed, A.; Sindhu, S. T. and Mohammad, G. (1993): "Bacteriology of camel lungs". Camel Newsletter, (10): 30-32.

- Seddek, S. R. (2002): 'Bacterial causes of lung affections in slaughtered camels in Assiut governate". Assiut Vet. Med. J., 46 (92): 169-177.

- Selim, M. A. (2003): Bacterial isolates from pneumonic lungs of dromedary camels slaughtered at Sharkia governate. Zag.Vet. J., 31(1): 63-69.

- Stamp,J.,Watt,J.and Thomliuson,J. (1959): Pasteurella haemolytica of calves. J. Comp. Path., 65: 183-186.

- Thabet, A. El. R. (1994): Some microbial studies of lung of clinically healthy and respiratory infected camels. Assiut Vet. Med. J., 30 (59): 188-195.

- Wessman, G. E. (1964): Inter-relation of smooth and non smooth variant in dissociation of Pasteurella haemolytica.J.Bact.,88: 325-360.

- Zubair, R.; Khan, A. M. Z. and Sabri, A. M. (2004): Pathology in camel's lungs. J. Camel Science. (1): 103-106. 


\section{الملخص العريي}

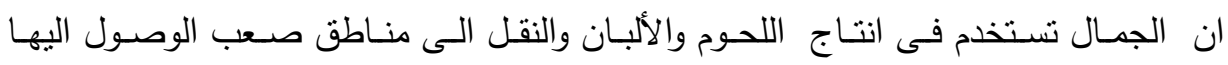
والالتهاب الرئوى فى الجمال مشكلة تؤثثر على انتاج الحيوان وتسبب خسائر خطيرة على اقتصاد

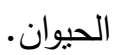

اجريت هذه الدراسة على 308 عينة من رئات الجمال المذبوحة منهم 205 عينة رئات سليمة ظاهريا و 103 عينة مصابة وقد وجد ان203 عينة بنسبة 65.91\% ايجابية للغزل البكتيرى منهم 124

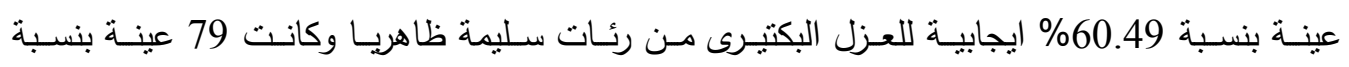

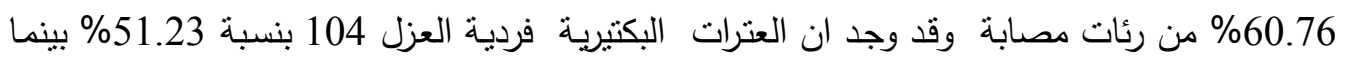
ثنائية العزل كانت 99 بنسبة 48.74\% منهم 74 بنسبة 68.59\% ايجابيـة للعزل الفردى من رئيات

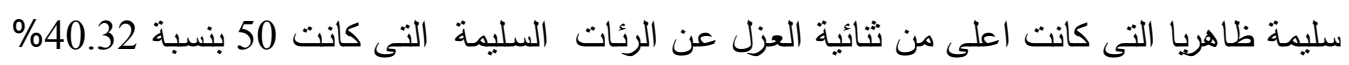

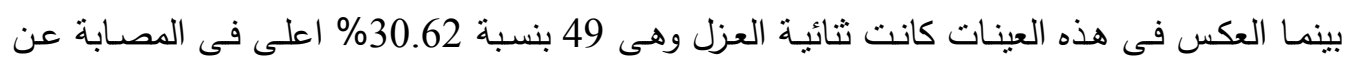
فردية العزل فى الرئات المصابة وهى 30 بنسبة 37.97\% وقد وجد ان العدد الكلى للمعزولات البكتيرية 302 منهم 174 من رئات سليمة ظاهريا و 128 من المعزولات من رئات مصابة وقد اوضح الفحص البكتيرى العدد الكلى لبكتيريا موجبة لصبغة الجرام

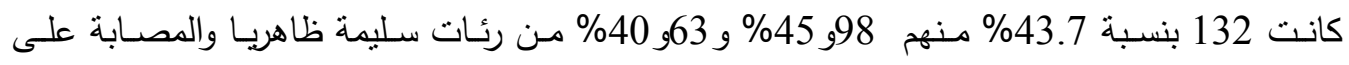
التوالى. كان اكثر العترات البكثيرية نواجدا بالنسبة للميكروبات الفردية العزل وايجابية لصبغة الجرام هى معزولات الميكروب السبحى بنسبة عزل 17 عينة (16.35\%) يليه الميكروب العنقودى الذهبى 12 عينة بنسبة (11.54\%) والميكروكوكس 6 عينات بنسبة (5.77\%) واركانوبكتبريم بيوجينس 3 عينات

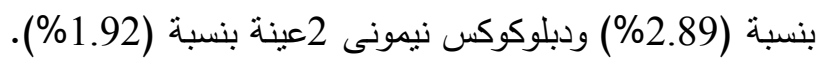

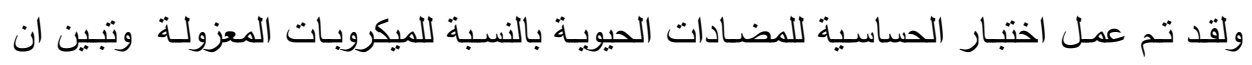
كلوكسييسلين ودوكسيسيكلين والانروفلوكساسين والجنتاميسين والنوروفلوكساسين هى الاكثر تاثثرا على بلى وتئ ميكروب اركانوبكتيريم بيوجينس بينما السيبروفلوكساسين وكلوكساسيلين والانروفلوكساسين والجنتاميسين

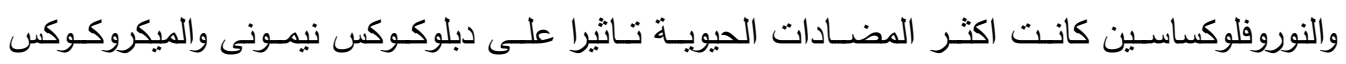
والميكروب السبحى والعنقودى الذهبى. 